\title{
The Role of Feeding Type in Salmonella Spp. Transmission
}

\author{
Zorița Maria COCORA ${ }^{1}$, Ioan ŢIBRU ${ }^{1}$ \\ ${ }^{1}$ Banat's University of Agricultural Science and Veterinary Medicine Timisoara, Faculty of Veterinary \\ Medicine, 300645, Calea Aradului, no 119, Timisoara, Romania \\ * Corresponding author e-mail: zoritzacocora@yahoo.com
}

Bulletin UASVM Veterinary Medicine 71(2) / 2014,

Print ISSN 1843-5270; Electronic ISSN 1843-5378

DOI:10.15835/buasvmcn-vm: 10310

\begin{abstract}
The infection with Salmonella in pigs farms is usually endemic and largely asymptomatic. The present study aimed the importance of feeding type (dry/wet) administered in the transmission of Salmonella in pigs farms.

We had studied two farms, one in which pigs received wet feeding and at the other the given ration was dry. From each farm were collected $100 \mathrm{fecal}$ and 50 feed samples.

After analyzing the samples collected, it was found that the number of positive samples on the farm were the ration was liquid, was $34 \%$ from the feces and (2\%) from the feed, which was reduced in comparison with the farm were the ration was dry, where the positive samples were $(61 \%)$ for feces, and $4 \%$ from feed.

The results support the ideas that liquid feeding ensures less chance of contamination by $27 \%$ compared to dry feeding, because is inducing an increases of organic acids which facilitates normal bacterial growth, leading to reduction of Salmonella.

Keywords: farms, feed, pigs, Salmonella spp. samples
\end{abstract}

Introduction. Pork and pork products are recognized as important sources of human salmonellosis (Smith et al. 2010). Salmonella is an important cause of food-borne (alimentary) health problems in humans (Hernandez et al. 2013). The risk of Salmonella might differ between the production systems, caused by components of the husbandry systems affecting disease development and pathogen shedding (Zheng et al. 2007), or differences in the level of resistance to the pathogen.

Aims and objectives. The objectives are to determine the carrier state of Salmonella spp. which received two types of dry and wet feed.

Materials and methods. The study was conducted in two fattening farms, from which in one was administered wet feeding and in the other dry feeding. In order to emphasize the importance of the type of feed, from farm were collected 100 feces samples from pigs and 50 feed samples.
Samples were collected in sterile containers and transported to the laboratory of Hygiene, being analyzed by EN ISO 6579:2002 method.

Results and discussion. After analyzing the obtained results, the farm that used wet feeding. In feces samples collected was found a prevalence of $34 \%$ compared with the farm that used dry feeding, where was observed a prevalence of $61 \%$. Analyzing and comparing the obtained results from the sampling of feed (50 samples), it was found a prevalence of $2 \%$ in the farm were was given dried feeding to a prevalence $2 \%$ in farm that used wet feed.

Fecal samples resulted in this study revealed that in the case of liquid feeding were fewer positive samples (figure 1).

The association of liquid feed and the reduction of Salmonella spp. prevalence was observed in other studies (Farzan et al. 2006). Dubroca et al. (2006) after a study conducted in 20 fattening farms in France, established that the prevalence of 


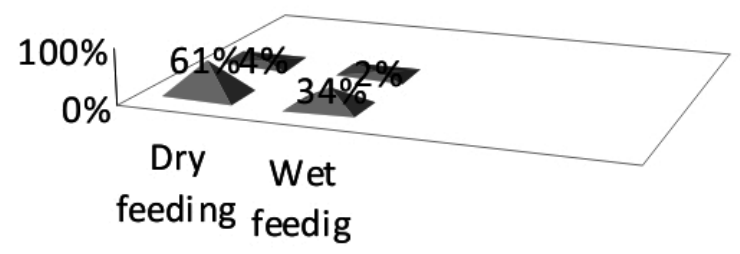

FAECES - FEED

Fig. 1. Prevalence with Salmonella spp. in the farm with wet and dry feed

Salmonella spp. in cecum was different depending on the type of feed. The seroprevalence was $21.5 \%$ for dried feed and $10.3 \%$ for wet feed, respectively $28.5 \%$ and $12.7 \%$ in case of cecum prevalence. There were situations where the studies made didn't found any differences (Rajic et al. 2007).

Conclusion. Administration of the liquid feed may result in a reduction of the state of carrier for Salmonella spp. The difference between the two farms studied was $27 \%$ in favor of the farm that used liquid feeding.

Acknowledgements: This paper was published under the frame of European Social Fund, Human Resources Development Operational Programme 2007-2013, projectno. POSDRU/159/1.5/S/132765.

\section{References}

1. Dubroca ., Correge I, Salaun Y (2006). Salmonella status in swine units characterization: Comparative study of serology and bacteriology. In: Proc. 19*1 IPVS Congress, Copenhagen, Denmark, 2, 367.
2. Farzan A, Friendship RM, Dewey CE, Warriner K, Poppe C, Klotins K (2006). Prevalence of Salmonella spp. on Canadian pig farms using liquid or dry-feeding. Prev Vet Med 73:241-254.

3. Hernandez M, Gomez-Laguna J, Tarradas C, Luque I, GarciaValverde R, Reguillo L, Astorga RJ (2013). A serological Survey of Brucella spp., Salmonella spp., Toxoplasma gondii and Trichinella spp. in Iberian Fattening Pigs Reared in Free-Range Systems. Trans-boundary and Emerging Diseases, Jan 7. DOI: 10.1111/tbed.12049. [Epub ahead of print].

4. Rajic, A, O'Connor, BP, Deckert, AE, Keenslide, J, McFall, ME, Reid-Smith, RJ, Dewey, CE, McEwen, SA (2007). Farmlevel risk factors for the presence of Salmonella in 89 Alberta swine-finishing bams. Can. J Vet Res 71: 264-270.

5. Smith RP, Clough HE, Cook AJC (2010). Analysis of meat juice ELISA results and questionnaire data to investigate farm-level risk factors for Salmonella infection in UK pigs. Zoonoses and Public Health 57(1):39-48.

6. Zheng DM, Bonde M, Sørensen JT (2007). Associations between the proportion of Salmonella seropositive slaughter pigs and the presence of herd level risk factors for introduction and transmission of Salmonella in 34 Danish organic, outdoor (non-organic) and indoor finishing-pig farms. Livest Sci 106:189-199. 